\section{Subacute Bacterial Endocarditis Presenting with Meningitis}

\section{Brit. med. F., 1965, 2, 1530}

The central nervous system is frequently involved in subacute bacterial endocarditis, producing suppurative, non-suppurative, and haemorrhagic lesions. However, these usually appear in the established case or are found at necropsy. It is unusual for such a complication to be a presenting feature. We now describe a case admitted with meningitis.

\section{Case Report}

A man aged 26 was admitted to hospital, having collapsed and then become confused. His speech had become unintelligible but he had not lost consciousness.

Relatives said that three weeks previously he had had a pain in the left arm which had partially improved. Similar pains then developed in the left leg and abdomen, causing him to lose a few days off work.

Ten days afterwards he had suddenly developed left-sided pleuritic pain. He had gone to a near-by hospital, and records obtained afterwards showed that he had had a temperature of $100.4^{\circ} \mathrm{F}$. $\left(38^{\circ} \mathrm{C}\right.$.), physical examination and radiograph of the chest being normal. A diagnosis of pleurisy was made, and he was given an injection of penicillin; this treatment was possibly continued by his own doctor in the form of tablets. He remained off work and gradually improved.

He had had no serious illnesses but had had a throat infection four months previously and had lost $1 \frac{1}{2} \mathrm{st}$. $(9.5 \mathrm{~kg}$.) during the month before admission. There was no history of rheumatic fever or chorea. His brother had had "chest trouble" four years previously.

On examination the temperature was $103^{\circ} \mathrm{F} .\left(39.5^{\circ}\right.$ C.). The patient was confused and euphoric, with expressive and receptive aphasia. Meningism was marked, with early papilloedema in the right fundus. The pulse was regular and collapsing, the bloodpressure $120 / 40 \mathrm{~mm}$. Hg. Signs of stenosis and incompetence of both mitral and aortic valves were apparent. The heart was not clinically enlarged. Finger- and toe-clubbing was obvious. The teeth were carious but there had been no recent extractions. Soft glands were palpable in the cervical, epitrochlear, and axillary regions.

The haemoglobin was 10.9 g. $/ 100 \mathrm{ml}$. (75\%), total white cells $9,400 /$ c.mm., polymorphonuclears $75 \%$, lymphocytes $23 \%$, monocytes $2 \%$, and the E.S.R. $30 \mathrm{~mm}$. (Wintrobe, corrected). The cerebrospinal fluid was cloudy and at a pressure of $170 \mathrm{~mm}$., showing no evidence of block. There was no xanthochromia or coagulum. It contained 30 red blood cells/c.mm. and 2,000 white blood cells, mostly polymorphs, per c.mm., protein $50 \mathrm{mg} . / 100 \mathrm{ml}$., glucose $36 \mathrm{mg} . / 100 \mathrm{ml}$., and chloride $116 \mathrm{mEq}(412 \mathrm{mg}$.) $/ 100 \mathrm{ml}$., with a slight excess of globulin. No organisms were seen in Gram and Ziehl-Neelsen preparations and it remained sterile.

After blood had been taken for culture and virus investigations, it was decided to treat the patient as for a pyogenic meningitis with parenteral penicillin and oral sulphonamides.

After 18 hours on this regime his temperature was still $102^{\circ} \mathrm{F}$ $\left(39^{\circ} \mathrm{C}\right.$.) and his mental state unchanged. Meningism had increased and the right ankle jerk was impaired. The cerebrospinal fluid remained sterile.

The treatment was changed to that appropriate to tuberculous meningitis-parenteral streptomycin, and para-aminosalicylic acid, isoniazid, and prednisone. His general condition rapidly improved, with fall of temperature and some slight improvement in mental state. The right pupil was now larger than the left, both still reacting normally to light and accommodation, and a right-sided lower-motor-neurone facial weakness appeared. Meningism lessened and the papilloedema disappeared.

By the end of the first week two blood cultures had grown Str. viridans. Parenteral penicillin was therefore added, the prednisone being gradually withdrawn.
Improvement continued with insight into his aphasia, recovery from the facial weakness, and return of the mental state to normal after about two and a half weeks. There was, however, an attack of central abdominal pain lasting a day, and for a few days there was localized tenderness between the left Achilles tendon and the tibia. The pupils continued to vary in size; at discharge the right was larger than the left, the cerebrospinal fluid being normal. The spleen was never palpable nor were red blood cells found in the urine, nor was there any cutaneous manifestation.

All chemotherapy was stopped after six weeks. Having remained apyrexial for 10 days, the patient was discharged home and returned to work a month later.

\section{Commént}

The neurological complications of subacute bacterial endocarditis were first described by Osler in 1885 (Osler and Macrae, 1935) and are now well documented. There may occur (Kerr, 1955) hemiplegia (with or without aphasia), cranial-nerve palsies, vomiting, psychosis, irritability, drowsiness, and coma. Meningitis may be purulent or sterile (Smith, 1939). There may be cerebral abscess, cerebral or subarachnoid haemorrhage, mycotic aneurysm, or encephalopathy. Cerebral arteritis may cause hemiplegia up to two years after the attack (Alajouanine et al., 1959a ; Alajouanine et al., 1959b). The more severe manifestations are rare, occur in the course of a florid endocarditis, and are usually fatal. When they occur early the clinical picture may be confusing, suggesting general paralysis of the insane, disseminated sclerosis, Schilder's disease, poliomyelitis, polyneuritis, encephalitis lethargica, or intracranial tumour (Kernohan et al., 1939). In more recent years tuberculous meningitis has appeared as the most important alternative (Stanton, 1952 ; Bergen and Dermksian, 1957).

In the present case, difficulty in diagnosis was enhanced by the initial lack of any history-it was obtained piecemeal during the first 10 days, and only then could a coherent picture of subacute bacterial endocarditis be built up. Presumably the abdominal and leg pains the patient had in hospital were similar to the limb and back pains before admission. Such pains are usually attributed to emboli.

An interesting point is the lack of response to penicillin alone during the first few days in hospital, though the unsuspected organism was subsequently shown to be fully sensitive to both penicillin and streptomycin. Only later was it learnt that penicillin had already been given before admission. Doubtless it was this which was responsible for the unusual presentation, sterilizing but not curing the meningitis. The use of streptomycin and steroids led to an immediate improvement. In view of the organism's sensitivity, it is tempting to suggest that the prednisone rather than the streptomycin was responsible for this.

My thanks are due to Dr. A. Freedman, of Hackney Hospital, for his permission to publish this case and for his belp in its preparation.

\section{London N.W.4. G. A. HARRIS, M.B., CH.B.}

\section{REFERENCES}

Alajouanine, T., Castaigne, P., and Lhermitte, F. (1959a). F. Amer. med. Ass., 170, 1856.

Ber - and Cambier, J. (1959b). Sem. Hop. (Paris), 35, 1160 ergen, S. S., jun., and Dermksian, G. (1957). N.Y. St. F. Med., 57, 3683.

Kernohan, J. W., Woltman, H. W., and Barnes, A. R. (1939). Arch. Neurol. Psychiat. (Chic.), 42, 789 .

Kerr, A., jun. (1955). Subacute Bacterial Endocarditis. Blackwell, Oxford. Osler, W. (1885). Brit. med. F., 1, 467.

- and McCrae, T. (1935). Principles and Practice of Medicine, 12th ed. Appleton, New York.

Smith, Wilson F. (1939). New Engl. 7. Med., 220, 587.

Stanton, A. (1952). N.Y. St. F. Med., 52, 467. 